\title{
A cross sectional study of depression during pregnancy and its risk factors among pregnant women attending a tertiary care hospital in Puducherry, India
}

\author{
Sabita P. ${ }^{1}$, Prakash M. ${ }^{2 *}$, Sharmila E. ${ }^{1}$ \\ ${ }^{1}$ Department of Obstetrics and Gynecology, ${ }^{2}$ Department of Community Medicine, Indira Gandhi Medical College and \\ Research Institute, Kathirkamam, Puducherry, India
}

Received: 15 March 2019

Accepted: 19 March 2019

\author{
*Correspondence: \\ Dr. Prakash M., \\ E-mail: drmanivelprakash@yahoo.co.in
}

Copyright: ( ) the author(s), publisher and licensee Medip Academy. This is an open-access article distributed under the terms of the Creative Commons Attribution Non-Commercial License, which permits unrestricted non-commercial use, distribution, and reproduction in any medium, provided the original work is properly cited.

\begin{abstract}
Background: Depression during pregnancy is a recognized global health issue which can lead to wide range of maternal and neonatal complications to extremes like maternal suicide to infanticide. This study was done to estimate the magnitude of depression during pregnancy and its risk factors among pregnant women attending a tertiary care hospital in Puducherry.

Methods: A descriptive cross sectional study was done among 220 pregnant women attending routine antenatal checkup in outpatient department of a tertiary care hospital in Puducherry, using a systematic random sampling technique. A semi structured questionnaire using Patient Health Questionnaire-9 was used to screen the mothers for antenatal depression.

Results: 220 pregnant women were evaluated for antenatal depression. Mean age of the study participants was $25.02 \pm 3.13$ years. Using PHQ-9 authors found that $19.5 \%$ pregnant women were having risk for antenatal depression, of which the mild, moderate and moderately severe levels of depression were $16.4 \%, 1.4 \%$ and $1.8 \%$ respectively. The risk of antenatal depression was statistically significant among the women age more than 30 years, husband's educational status as higher secondary and below, residence in rural area, multigravida, having a male child, strained relationship, no support during pregnancy and pressure for a male child. Logistic regression analysis revealed age $\geq 30$ years (aOR 3.03, 95\% CI 1.04-8.82), and no support during pregnancy (aOR 3.30, 95\% CI 1.10-9.90) were the significant factors.

Conclusions: Since the risk for antepartum depression is huge in this region, there is a need for screening for antepartum depression as a routine antenatal checkup in the out patient department. Reinforcing the importance of appropriate for conception and support for the mother during pregnancy plays a vital role in reducing the magnitude of this depression.
\end{abstract}

Keywords: Antenatal, Depression, PHQ-9, Support

\section{INTRODUCTION}

Depression during pregnancy is recognized as a global health issue due to its high prevalence, negative influence on the maternal and foetal outcome and susceptibility for postnatal depression. ${ }^{1-6}$ This substantial effect on child and women can lead to wide range of maternal and neonatal complications to extremes like maternal suicide to infanticide. Several studies have documented prevalence ranges from $4 \%$ to $25 \% .^{2,4,5,7-13}$ Other studies 
using a variety of depression assessment tools have reported antenatal depression prevalence of $9 \%$ to $28 \%$ for predominantly middle class samples and $25 \%$ to $50 \%$ for low income populations. ${ }^{14-16}$ It is persistently under diagnosed and treated during antenatal care and is largely ignored especially in developing countries as it is attributed to the insignificant changes during pregnancy. Even in the history less attention has been paid to the depression in the antepartum period than postpartum. As there is $45 \%$ increase in the antepartum depression (APD) recent past makes it a matter of great importance. ${ }^{17}$

Risk factors attributable for the development of antenatal depression include young age, multiparity, place of residence, low income, lower educational attainment, history of depression, previous poor obstetrical outcome, previous history of depression, strained relationships with family members, type of family and support from family ,gender preference and pressure ,history of childhood sexual abuse, adverse events in the recent past and low social support. The prevalence of depression is to some extent higher in rural population compared to those in urban areas. Studies have reported different prevalence in rural and urban population, south India-16.2\%, rural Chennai-65\%, urban areas like Navi-Mumbai $18 \%$ and Delhi 5-26\%., ${ }^{9,17-20}$ Different types of scales were used in these studies. Despite being an important public health issue, there is paucity of data on depression during pregnancy. Hence, this study was conducted with an aim to find the prevalence of depression during pregnancy, its attributable risk factors and to find out the pattern of prevalence and risk factors between urban and rural pregnant women attending tertiary care hospital in Puducherry.

\section{METHODS}

This is a descriptive cross-sectional type of study in the outpatient department (OPD) of obstetrics in a tertiary care hospital in Puducherry. The total sample size taken was 220 pregnant women attending routine antenatal checkup in outpatient department of Indira Gandhi Medical College and Research Institute, Puducherry. The study was done after getting informed consent. Pregnant women with pre-existing medical and surgical complications requiring hospitalization and pregnant women with pre-existing known psychiatric illness were excluded from this study.
Assuming the prevalence of antepartum depression as $10 \%$, with error of margin as $10 \%$ and design effect as 2 , the sample size was calculated as 193 . With the addition of $10 \%$ non-response rate, the final sample size was rounded to 220. Systematic random sampling method (every third eligible study participant) was used as sample collecting procedure. After obtaining the social and demographic data a standardized and internationally accepted questionnaire, Patient Health Questionnaire-921 (PHQ 9) was used for the diagnosis of depressive disorders and was applied to screen all the subjects. The subjects identified as having depressive disorder was referred to psychiatry department and confirmed by a psychiatrist. The identified cases were treated as per treatment protocol followed at Psychiatry Unit in Indira Gandhi Medical College and Research Institute.

\section{Statistical analysis}

Descriptive data was tabulated as means, standard deviation, frequency and percentages. Fisher's Exact test or Chi-square test was applied to study the association between antenatal depression and the risk factors. Logistic regression analysis was also done to find the confounding factors and determine the adjusted odd's ratio for the risk factors. Data processing and analysis was done in MS Excel 2013, Epi info and SPSS version 20.0. $\mathrm{P}$ value $<0.05$ was considered as significant.

\section{RESULTS}

A total of 220 pregnant women participated in this study. Mean age of the study participants was $25.02+3.13$ years. The prevalence of different levels of depression assessed using PHQ-9 of the study subjects has been shown in Table 1. Overall $19.5 \%$ of the pregnant women were having depression where $16.4 \%, 1.4 \%$ and $1.8 \%$ were suffering from mild, moderate and moderately severe levels of depression respectively.

The descriptive profile socio-demographic characteristics and its association with antepartum depression have been shown in Table 2 . About $10 \%$ of the study subjects were aged 30 years and above. All of the pregnant mothers were married. Almost half of the pregnant women were graduate whereas approximately $3 / 4^{\text {th }}$ of their husbands were graduate.

Table 1: Prevalence of different levels of depression among pregnant women.

\begin{tabular}{|l|l|l|l|l|l|}
\hline Depression levels & Frequency & Percent & Depression category & Frequency & Percent \\
\hline None-minimal & 177 & 80.5 & Depression absent & 177 & 80.5 \\
\hline Mild & 36 & 16.4 & Depression present & 43 & 19.5 \\
\hline Moderate & 3 & 1.4 & & 220 & 100.0 \\
\hline Moderately severe & 4 & 1.8 & & 20 \\
\hline Total & 220 & 100.0 & & \\
\hline
\end{tabular}


Table 2: Association between socio-demographic characteristics and antepartum depression.

\begin{tabular}{|c|c|c|c|c|c|c|}
\hline \multicolumn{2}{|l|}{ Variable } & \multirow{2}{*}{$\begin{array}{l}\text { Depression } \\
\text { present (\%) } \\
10(45.5)\end{array}$} & \multirow{2}{*}{$\begin{array}{l}\text { Depression } \\
\text { absent (\%) } \\
12(54.5)\end{array}$} & \multirow{2}{*}{$\begin{array}{l}\text { Total }(\%) \\
22(10.0)\end{array}$} & \multirow{2}{*}{$\begin{array}{l}\text { Odd's ratio } \\
\text { (95\% CI) } \\
4.17(1.67-10.44)\end{array}$} & \multirow{2}{*}{$\begin{array}{l}\text { p value } \\
0.003^{*}\end{array}$} \\
\hline & $\geq 30$ & & & & & \\
\hline Age group (years) & $<30$ & $33(16.7)$ & $165(83.3)$ & $198(90.0)$ & - & - \\
\hline Marital status & Married & $43(19.5)$ & $177(80.5)$ & $220(100.0)$ & - & - \\
\hline \multirow{2}{*}{$\begin{array}{l}\text { Educational } \\
\text { status of the subjects }\end{array}$} & $\begin{array}{l}\text { Up to higher } \\
\text { secondary }\end{array}$ & $22(20.8)$ & $84(79.2)$ & $106(48.2)$ & $1.16(0.6-2.26)$ & 0.663 \\
\hline & $\begin{array}{l}\text { Graduate/Post } \\
\text { graduate }\end{array}$ & $21(18.4)$ & $93(81.6)$ & $114(51.8)$ & 1 & - \\
\hline \multirow{2}{*}{$\begin{array}{l}\text { Educational } \\
\text { status of the husband }\end{array}$} & $\begin{array}{l}\text { Up to higher } \\
\text { secondary }\end{array}$ & $16(32.0)$ & $34(68.0)$ & $50(22.7)$ & $2.49(1.21-5.13)$ & 0.012 \\
\hline & $\begin{array}{l}\text { Graduate/Post } \\
\text { graduate }\end{array}$ & $27(15.9)$ & $143(84.1)$ & $170(77.3)$ & 1 & - \\
\hline \multirow{2}{*}{$\begin{array}{l}\text { Monthly } \\
\text { income }\end{array}$} & Up to 3126 & $4(33.3)$ & $8(66.7)$ & $12(5.5)$ & $2.17(0.62-7.56)$ & 0.215 \\
\hline & 3127 and above & $39(18.8)$ & $169(81.2)$ & $208(94.5)$ & 1 & - \\
\hline \multirow{2}{*}{$\begin{array}{l}\text { Type of } \\
\text { family }\end{array}$} & Joint & $18(18.8)$ & $78(81.2)$ & $96(43.6)$ & $0.91(0.47-1.79)$ & 0.793 \\
\hline & Nuclear & $25(20.2)$ & $99(79.8)$ & $124(56.4)$ & & \\
\hline \multirow{2}{*}{ Residence } & Rural & $30(27.3)$ & $80(72.7)$ & $110(50.0)$ & $2.80(1.37-5.72)$ & 0.004 \\
\hline & Urban & $13(11.8)$ & $97(88.2)$ & $110(50.0)$ & & \\
\hline \multirow{2}{*}{$\begin{array}{l}\text { Family h/o } \\
\text { psychiatric disorders }\end{array}$} & No & $42(19.4)$ & $175(80.6)$ & $217(98.6)$ & & \\
\hline & Yes & $1(33.3)$ & $2(66.7)$ & $3(1.4)$ & $2.08(0.19-23.52)$ & $0.481 *$ \\
\hline \multirow{2}{*}{ Past h/o abortions } & No & $38(18.7)$ & $165(81.3)$ & $203(92.3)$ & $0.55(0.18-1.66)$ & $0.337 *$ \\
\hline & Yes & $5(29.4)$ & $12(70.6)$ & $17(7.7)$ & & \\
\hline \multirow{2}{*}{ Past h/o stillbirth } & No & $42(19.4)$ & $174(80.6)$ & $216(98.2)$ & $0.72(0.07-7.14)$ & $0.584 *$ \\
\hline & Yes & $1(25.0)$ & $3(75.0)$ & $4(1.8)$ & & \\
\hline
\end{tabular}

Table 3: Association between anticipated risk characteristics and antepartum depression.

\begin{tabular}{|c|c|c|c|c|c|c|}
\hline \multicolumn{2}{|l|}{ Variable } & \multirow{2}{*}{$\begin{array}{l}\text { Depression } \\
\text { present (\%) } \\
21(29.2)\end{array}$} & \multirow{2}{*}{$\begin{array}{l}\text { Depression } \\
\text { absent (\%) } \\
51(70.8)\end{array}$} & \multirow{2}{*}{$\begin{array}{l}\text { Total (\%) } \\
72(32.7)\end{array}$} & \multirow{2}{*}{$\begin{array}{l}\text { Odd's ratio } \\
\text { (95\% CI) } \\
2.36(1.19-4.66)\end{array}$} & \multirow{2}{*}{$\begin{array}{l}\text { p value } \\
0.012\end{array}$} \\
\hline & Yes & & & & & \\
\hline Multigravida & No & $22(14.9)$ & $126(85.1)$ & $148(67.3)$ & & \\
\hline \multirow{2}{*}{ Male } & One & $15(36.6)$ & $26(63.4)$ & $41(18.6)$ & $3.11(1.47-6.60)$ & 0.002 \\
\hline & None & $28(15.6)$ & $151(84.4)$ & $179(81.4)$ & & \\
\hline \multirow{2}{*}{ Female } & One/Two & $7(21.2)$ & $26(78.8)$ & $33(15.0)$ & $1.13(0.45-2.81)$ & 0.793 \\
\hline & None & $36(19.3)$ & $151(80.7)$ & $187(85.0)$ & & \\
\hline \multirow{2}{*}{$\begin{array}{l}\text { Previous pregnancy } \\
\text { complications }\end{array}$} & No & $40(19.2)$ & $168(80.8)$ & $208(94.5)$ & & \\
\hline & Yes & $3(25.0)$ & $9(75.0)$ & $12(5.5)$ & $1.40(0.36-5.38)$ & $0.707 *$ \\
\hline \multirow{2}{*}{$\begin{array}{l}\text { Strained } \\
\text { relationship }\end{array}$} & No & $36(17.9)$ & $165(82.1)$ & $201(91.4)$ & & \\
\hline & Yes & $7(36.8)$ & $12(63.2)$ & $19(8.6)$ & $2.67(1.01-7.05)$ & $0.066^{*}$ \\
\hline \multirow{2}{*}{ Support pregnancy } & Yes & $34(16.8)$ & $168(83.2)$ & $202(91.8)$ & & \\
\hline & No & $9(50.0)$ & $9(50.0)$ & $18(8.2)$ & $4.94(1.83-13.36)$ & $0.002 *$ \\
\hline \multirow{2}{*}{ Husband alcoholic } & Yes & $11(20.0)$ & $44(80.0)$ & $55(25.0)$ & $1.04(0.48-2.23)$ & 0.922 \\
\hline & No & $32(19.4)$ & $133(80.6)$ & $165(75.0)$ & & \\
\hline \multirow{2}{*}{$\begin{array}{l}\text { Expectation male } \\
\text { child }\end{array}$} & Yes & $8(33.3)$ & $16(66.7)$ & $24(10.9)$ & $2.30(0.91-5.80)$ & $0.098^{*}$ \\
\hline & No & $35(17.9)$ & $161(82.1)$ & $196(89.1)$ & & \\
\hline \multirow{2}{*}{$\begin{array}{l}\text { Fear of female } \\
\text { child }\end{array}$} & Yes & $2(66.7)$ & $1(33.3)$ & $3(1.4)$ & $8.59(0.76-96.97)$ & $0.098 *$ \\
\hline & No & $41(18.9)$ & $176(81.1)$ & $217(98.6)$ & & \\
\hline \multirow{2}{*}{ Pressure male child } & Yes & $3(75.0)$ & $1(25.0)$ & $4(1.8)$ & $13.20(1.34-130.23)$ & $0.024 *$ \\
\hline & No & $40(18.5)$ & $176(81.5)$ & $216(98.2)$ & & \\
\hline \multirow{2}{*}{$\begin{array}{l}\text { Worried about } \\
\text { child health }\end{array}$} & Yes & $41(19.0)$ & $175(81.0)$ & $216(98.2)$ & $0.23(0.03-1.71)$ & $0.172 *$ \\
\hline & No & $2(50.0)$ & $2(50.0)$ & $4(1.8)$ & & \\
\hline
\end{tabular}

*Fisher's Exact test. Chi-square test. 
Table 4: Logistic regression analysis to predict risk factors antepartum depression.

\begin{tabular}{|l|l|l|l|l|}
\hline Variable & p value & AOR & \multicolumn{2}{c|}{ 95\% C.I. for AOR } \\
\hline Age ( $\geq 30$ years) & 0.042 & 3.030 & 1.040 & Upper \\
\hline Husband education (up to higher secondary) & 0.153 & 1.936 & 0.782 & 4.795 \\
\hline Residence (rural) & 0.224 & 1.723 & 0.717 & 4.138 \\
\hline Previous neonatal outcome (yes) & 0.968 & 0.978 & 0.325 & 2.941 \\
\hline Male (yes) & 0.164 & 2.310 & 0.711 & 7.507 \\
\hline Support (No) & 0.033 & 3.299 & 1.099 & 9.899 \\
\hline Constant & 0.010 & 0.145 & & \\
\hline
\end{tabular}

About $5.5 \%$ pregnant mothers family were earning lesser than 3126Rs per month. Most of them (46\%) were living in a nuclear family. Half of the pregnant mothers were from rural area. About $1.4 \%$ of the pregnant mothers were having family history of psychiatric disorders. About $7.7 \%$ of the pregnant mothers were having a past history of abortion and $1.8 \%$ were having past history of stillbirth. In the univariate analysis, the significant factors associated with antepartum depression were age more than 30 years, husbands' educational status as higher secondary and below and residence in rural area

The descriptive characteristics and some factors associated with antepartum depression have been shown in Table 3. About $33 \%$ of the pregnant women were multigravida. Out of these $33 \%$ multigravida, almost $57 \%$ of the women were having a male child and $46 \%$ were having one or two female children. About 5.5\% mothers had complications during previous pregnancy. Almost $9 \%$ of the pregnant mothers had strained relationship and about $8 \%$ were not having any support during pregnancy. One fourth of the husbands were alcoholic. Approximately $11 \%$ of the mothers were expecting a male child. $1.4 \%$ of the mothers were having a fear for female child. $1.8 \%$ of the mothers were having a pressure for a male child. Majority $(98 \%)$ were worried about child's health. In the univariate analysis, the significant factors associated with antepartum depression were multigravida, having a male child, strained relationship, no support during pregnancy and pressure for a male child.

Table 4, the variable which were found to significant from univariate analysis $(\mathrm{p}<0.05)$ in Table 2 and 3 were considered for logistic regression analysis. However, on further analysis using binary logistic regression, only two risk factors were found to be associated significantly with high risk of depression out of 8 variables in the univariate analysis. These were age $\geq 30$ years (aOR 3.03, 95\% CI 1.04-8.82), and support during pregnancy (aOR 3.30, 95\% CI 1.10-9.90), as presented in Table 4.

\section{DISCUSSION}

In present study the prevalence of depression among antenatal mothers was $19.4 \%$ which was contributed by equal number of rural and urban mothers and our prevalence is within the range of (5-25\%) reported by several other studies with different rating scales. ${ }^{2,4,5,7-13}$ There are many risk factors for APD. present study mainly concentrated on socio demographic characteristics, previous pregnancy outcomes, type of family, support during pregnancy, past medical history, events in the recent past and abuse history. The results showed that all were married and had planned pregnancies. There were no unwanted pregnancies in present study. In accordance to the study conducted in America, present study also showed that as the maternal age increases the chance of developing depression during pregnancy increased. ${ }^{7}$ The risk of depression is higher among the multigravida (29\% vs14\%) than primigravida. studies done at Turkey, south India and Navi Mumbai also showed greater prevalence among multigravida and multipara whereas Set $\mathrm{N}$ al showed contrary findings that the risk of development of depression due to the acute mental stress experiences by pregnant women was same in the primi and multi gravidas. ${ }^{17-19,22}$

Peen et al, reported that the prevalence of depression during pregnancy was higher among urban mother than their counterparts in rural areas similarly crossmatched community based study from urbanized village of East Delhi showed the prevalence rates are $25.5 \%$ while other studies found an inverse correlation similar to present study. ${ }^{23-26}$

Present study found that educational status of spouse shows higher rate of depression with low literacy (up to higher secondary) but mother educational status did not have any effect. Probably the educational status of the male was lower than the female gives rise to stress to female to get adjusted in the family situations.

Other social factors like family income, type of family, expectation of male child, previous two female child, husband alcoholism, fear of female child and strained relationship, previous obstetrical outcome, past adverse life events, past and family history of depression does not have any effect on the development of depression during pregnancy. However, Nivetha et al study, showed all of these are attributable risk factors for development of depression during pregnancy. ${ }^{17}$ Authors found that lack 
of support from the family during pregnancy and pressure of male child were significant risk factors

Present study is a cross sectional study, but sensitive issues can be picked up only after repeated probing on several occasions during their antenatal care. So present antenatal visits are ideal option to screen these women during antenatal period and preventive steps can be taken for the development of postpartum depression. Early diagnosis of these conditions allow us to interfere with treatment so that maternal and child health can be taken care.

Longitudinal study designs are recommended to evaluate risk factors in detail. Increasing trend of depression in rural community needs to be evaluated further by taking comparative longitudinal studies with their urban counter parts.

\section{CONCLUSION}

To conclude, present study had shown that depression during pregnancy is prevalent in the age group of $>30$ years, with less literacy of husband and residing at rural areas and multiparity. Support from family and pressure male child was also significant risk factors for the development of depression during pregnancy.

\section{Funding: No funding sources}

Conflict of interest: None declared

Ethical approval: The study was approved by the Institutional Ethics Committee

\section{REFERENCES}

1. Teixeira C, Figueiredo B, Conde A, Pacheco A, Costa R. Anxiety and depression during pregnancy in women and men. J Affec Disord. 2009;119:142-8.

2. Pereira PK, Lovisi GM, Pilowsky DL, Lima LA, Legay LF. Depression during pregnancy: Prevalence and risk factors among women attending a public health clinic in Rio de Janeiro, Brazil. Cad Saude Publica. 2009;25:2725-36.

3. Bansil P, Kuklina EV, Meikle SF, Posner SF, Kourtis AP, Ellington SR, et al. Maternal and fetal outcomes among women with depression. J Womens Health (Larchmt). 2010;19:329-34.

4. Wissart J, Parshad O, Kulkarni S. Prevalence of preand postpartum depression in Jamaican women. BMC Preg Childbirth 2005;5:15.6.

5. Heron J, O'Connor TG, Evans J, Golding J, Glover $\mathrm{V}$; ALSPAC Study Team. The course of anxiety and depression through pregnancy and the postpartum in a community sample. J Affec Disord. 2004;80:65-73.

6. Johanson R, Chapman G, Murray D, Johnson I, Cox J. The North Staffordshire maternity hospital prospective study of pregnancy-associated depression. J Psychosom Obstet Gynaecol. 2000;21:93-7.
7. Rich-Edwards JW, Kleinman K, Abrams A, Harlow BL, McLaughlin TJ, Joffe $\mathrm{H}$, et al. Sociodemographic predictors of antenatal and postpartum depressive symptoms among women in a medical group practice. J Epidemiol Community Health. 2006;60:221-7.

8. Adewuya AO, Ola BA, Aloba OO, Dada AO, Fasoto OO. Prevalence and correlates of depression in late pregnancy among Nigerian women. Depress Anxiety. 2007;24:215-9.

9. Faisal-Cury A, Rossi Menezes P. Prevalence of anxiety and depression during pregnancy in a private setting sample. Arch Womens Ment Health. 2007;10:25-32.

10. Ryan D, Milis L, Misri N. Depression during pregnancy. Can Fam Physician. 2005;51:1087-93.

11. Lee DT, Chan SS, Sahota DS, Yip AS, Tsui M, Chung TK. A prevalence study of antenatal depression among Chinese women. J Affect Disord. 2004;82:93-9.

12. Evans J, Heron J, Francomb H, Oke S, Golding J. Cohort study of depressed mood during pregnancy and after childbirth. BMJ. 2001;323:257-60.

13. Joseffson A, Berg G, Nordin C, Sydsjö G. Prevalence of depressive symptoms in late pregnancy and postpartum. Acta Obstet Gynecol Scand. 2001;80:251-5.

14. Hobfoll SE, Ritter C, Lavin J, Hulsizer MR, Cameron RP. Depression prevalence and incidence among inner-city pregnant and postpartum women. J Consult Clin Psychol. 1995;63:445-53.

15. Séguin L, Potvin L, St-Denis M, Loiselle J. Depressive symptoms in the late postpartum among low socioeconomic status women. Birth. 1999;26:157-63.

16. Chung EK, McCollum KF, Elo IT, Lee HJ, Culhane JF. Maternal depressive symptoms and infant health practices among low-income women. Pediatr. 2004;113:e523-9.

17. Srinivasan N, Murthy S, Singh AK, Upadhyay V, Mohan SK, Joshi A. Assessment of burden of depression during pregnancy among pregnant women residing in rural setting of chennai. J Clin Diagn Res. 2015;9(4):LC08-12.

18. Kumar N, Bhagwan D, Singh N, D'Souza M, Bhaskaran U, Thapar R, et al. Risk factors for antenatal depression among women attending tertiary care hospitals in coastal part of South India. Nat J Comm Med. 2017;8(9):517-20.

19. Ajinkya S, Jadhav PR, Srivastava NN. Depression during pregnancy: Prevalence and obstetric risk factors among pregnant women attending a tertiary care hospital in Navi Mumbai. Ind Psychiatry $\mathbf{J}$. 2013;22:37-40.

20. Shaily M, Yatan PB, Rohit V, Shachi M. Anxiety and Depression amongst the urban females of Delhi in Ante-partum and Post-partum period. Delhi Psychiatry J. 2012;15(2):347-51. 
21. Kroenke K, Spitzer RL, Williams JB. The PHQ-9: validity of a brief depression severity measure. J Gen Intern Med. 2001;16(9):606-13.

22. Cankorur VS, Abas M, Berksun O, Stewart R. Social support and the incidence and persistence of depression between antenatal and postnatal examinations in Turkey: a cohort study. BMJ. 2015;5:e006456

23. Peen J, Schoevers R, Beekman A, Dekker J. The current status of urban-rural differences in psychiatric disorders. Acta Psychiatrica Scandinavica. 2010;121(2):84-93.

24. Priya A, Chaturvedi S, Bhasin SK, Bhatia MS, Radhakrishnan G. Depression, anxiety and stress among pregnant women: A community-based study. Indian J Psychiatry. 2018;60:151-2.
25. Jarahi, L, Zavar, A, Neamat Shahi M. Evaluation of Depression and related factors in pregnant women referred to urban and rural health centers of Sarakhs. J Midwifery Reprod Health. 2015;3(2):343-8.

26. Rahman A, Hayat Y, Habib Z, Iqbal J. Rural-Urban is parities in Khyber Pakhtunkhwa Pakistan. Sarhad J Agriculture. 2011;27(3):477-83.

Cite this article as: Sabita $\mathrm{P}$, Prakash M, Sharmila E. A cross sectional study of depression during pregnancy and its risk factors among pregnant women attending a tertiary care hospital in Puducherry, India. Int J Reprod Contracept Obstet Gynecol 2019;8:1363-8. 